\author{
Mel Cohen, Miami University Middletown
}

The classroom is core to the educational process. It is here that university community begins and teachers "... create the common ground of intellectual commitment (Carnegie Foundation for the Advancement of Teaching 1990, 12). Uninspiring classrooms where students are rarely motivated and where instructors, sometimes out of despair, do little more than mechanically cover the material need to be brought to life. The classroom experience is too important to be surrendered to despair and uninspired teaching. Class participation, by bringing students actively into the educational process, provides one means for enhancing our teaching and bringing life to the classroom.

A recent report on the state of higher education, while recognizing the important role played by lectures, stresses the need for a variety of teaching styles. Seeing the passive student as "one of the greatest challenges facing higher education," it recommends the increased use of active modes of teaching that require students to take greater responsibility for their learning. Among the modes recommended are small group discussions, simulations, in-class presentations, and debates (Study Group on the Conditions of Excellence in American Higher Education 1984, 27). Chickering, Gamson, and Barsi are even more emphatic in asserting that:

Learning is not a spectator sport. Students do not learn much just sitting in classes listening to teachers, memorizing pre-packaged assignments, and spitting out answers. They must talk about what they are learning, write about it, relate it to past experiences, and apply it to their daily lives. They must make what they learn part of thmselves. $(1989,12)$

\section{Some Means of Providing Class Participation}

Class participation comes in all shapes and sizes ranging from brief class discussion techniques to more elaborate simulations and games. Some techniques take a few minutes, others a number of class periods. What follows is a discussion of some simpler techniques that are easily implemented, very flexible, and require little special preparation by students or instructors. Some of these suggestions are original; others are adapted from or inspired by the

Class participation, by bringing students actively into the educational process, provides one means for enhancing our teaching and bringing life to the classroom.

work of others including Andrews (1980), Day (1987), Elbow (1986), and Frederick (1981). In all cases I have used them in my own classes and found that they increase student involvement in the learning process and help bring life to the classroom.

While the following suggestions are appropriate for classes of varying size, class size cannot be ignored. In addition to the management problems involved, students in larger classes may be hesitant to risk presenting their individual views in front of a large group. Instructors faced with classes of $60-80$ can easily adapt the following techniques to their classes. In most cases this can be done by dividing the class into small groups of 2-4 students. Once the members of the small groups discuss the question being asked, the class as a whole comes back together with the groups as the participants rather than each individual student. In this way, participation is both more likely and more manageable.

\section{The Five-Word Game}

This is a very flexible exercise that I have used to initiate discussions of both assigned readings and basic terminology. When analyzing a text (e.g., Marx and Engels, The Communist Manifesto; Burke, Reflections on the Revolution in France; Cohen and Rogers, On Democracy; Hummel, The Bureaucratic Experience), I ask students to come to class with five words that best describe the major ideas in the reading for the day. Their words may be taken directly from the text, but need not be. "Incomprehensible," "ridiculous," or "thoughtful" are appropriate choices though they may not be in the text itself. However, the students are told that they will need to support the basis for their word choices by citing relevant passages from the assigned material.

At the beginning of class seven or eight students are asked to volunteer one of their words to be put on the board. Next to each word I place the name or initials of the student who selected it. Each word is then discussed, and the student chooses passages from the text to explain why he or she chose that particular word. If properly handled, a discussion of the students' words will enable one to assess student comprehension and feelings about the text in addition to having a lively and thorough discussion of the assigned material. For example, when discussing The Communist Manifesto such words as "classes," "materialistic," "industry," "radical," "property," "market," "struggle," "equality," "anger," and "bourgeois" were selected by students. Based on these words and the related passages, it was possible to cover the essence of the work and at the same time bring students into the process of engaging a text.

This exercise is particularly wellsuited for the more reticent students who do not respond well under pres- 
sure or who may not feel at ease with the subject matter or our discipline. A simple task such as choosing words and supporting text is a task that can easily be handled by most students. It does not require that they be experts on the entire text nor that the entire text be mastered before coming to class. It requires only that they be willing to engage the text, even if tentatively.

Because of these features, I have used the five-word game to introduce students to the subject matter of political science. At the first class meeting of "American Political System," I ask students to write five words that come to mind when they hear the word "politics." After a number of words have been volunteered for the board, I ask each student to briefly comment about his or her choice. Following this, I ask students to use their own list of five words to write a short description of what they see politics to be. The students then exchange papers and read what others have said. Three or four students who feel that what they have read is well written are asked to put these descriptions on the board (normally one to four sentences) and to say a few words about why they feel this is a good description. These descriptions then serve as a starting point for a more in-depth discussion of the concept of politics (e.g., Does politics always involve compromise? Does politics take place outside of government? What common conceptions does the class hold about politics?).

A tool as simple as the five-word exercise contributes in multiple and specific ways to class participation. By using it the first day of class I give the students a clear message that participation will in fact take place and that they will be part of the learning process, not merely passive receptors of information. Students also begin to feel a sense of control since they have chosen the important words and written the descriptions that serve as the basis of discussion. The instructor's job then becomes one of clarifying and expanding, elaborating and synthesizing. Rather than being only a dispenser of information, the teacher becomes a guide in the thinking and learning process. Finally, when students coherently integrate their five words in a written descriptive statement they are engaging in the higher order reasoning and synthesizing that many have difficulty mastering.

\section{Simple Role Playing}

Role playing is a powerful learning technique that can easily be integrated into one or two 50-minute class periods. In introductory American politics courses, free expression court cases provide excellent opportunities for simple role playing. Cases such as Schenck v. U.S. (249 U.S.

\section{A simple task such as choosing words and} supporting text is a task that can easily be handled by most students. It does not require that they be experts on the entire text nor that the entire text be mastered before coming to class.

47, 1919), Cohen v. California (403 U.S. 15, 1971) or the more recent example of Texas $v$. Johnson (109 S.Ct. 2533, 1989) engage the students' interest and attention almost immediately. After describing the facts of the case, I ask the students to indicate by a show of hands whether they think the appellant or appellee should win. Not who did win, but whom the students would have supported had they been a member of the Supreme Court. If some students are not sure how they would decide the case, they can so indicate as well.

Following the show of hands, I inform the class that the case is now to be argued before the Court. Those who chose the appellant are to argue for the appellant; those who chose the appellee for the appellee. The persons who could not decide which side they favored are to serve as justices. During the proceedings each side is to present its best arguments based on the same facts that were before the Court. Prior to the proceedings, students may be given a short time to develop arguments individually or by meeting in small groups. Once the proceedings begin, the procedure may be informal with each student participating as in a debate or structured with representatives of each side presenting their arguments. The justices are to ask any necessary questions and ultimately render a decision. Once the discussion begins, justices are in control. In my classes the rules are rather loose since I am not particularly interested in the niceties of procedure before the Court for the purposes of this introductory course. Instead, I am more concerned with the nature of the analysis and logic used by the students in justifying a given position.

After hearing the arguments from both sides, the justices render a decision. Along with the judgment each justice explains the logic of his or her vote. Thus far I have had the justices vote one by one in public. By having each justice respond individually, each person needs to offer an explanation of why they voted a particular way and thus take responsibility for their vote. At the moment the court is rendering its decision, students are highly engaged. All eyes and ears are focused on the justices. Students really seem to care whether or not their arguments carried the day, and justices do try to convince the spectators of the legal and logical bases of their vote.

Student engagement remains high once the court has rendered its judgment. At this time I read and discuss excerpts from the actual majority and dissenting view in the Supreme Court case just discussed by the students. Before reading the opinion excerpts, I tell students that they should be thinking about what took place during the simulation (e.g., the arguments used, the logic of the Court's decision) and comparing it with what is being said in the opinion actually rendered by the Supreme Court. Students frequently find, to their pleasure, that the points and arguments they presented during the role-playing exercise are similar to those the justices actually considered. Furthermore, even those who are on 
the "losing side" of the Court's judgment need not see themselves as being wrong or as failures. While the Court may issue a majority opinion that agrees with the views of a portion of the students, just as in the class there is typically dissent on the Court. Not agreeing with the Court's opinion does not necessarily mean that one is wrong. It simply means that one is in the minority.

"Modern Political Ideologies"' is another course in which student role playing can be effectively used, in this case to demonstrate knowledge and understanding of original writings. For example, after in-class discussions of excerpts from two authors (e.g., Milton Friedman, Capitalism and Freedom, and George Will, Statecraft as Soulcraft), students are asked with which author's ideas they more agree. As with the above exercise using Court decisions, uncertainty is a valid initial choice for those who cannot decide which ideas they prefer. Those who are uncertain are then asked to serve as moderators of a discussion between the two authors being studied. Participants are to take on the role of their preferred author based on material from the readings and previous class discussion. The moderators' task is to focus the discussion by posing questions, questions that help the undecided (i.e., the moderators) to ultimately decide which side they prefer and why.

Prior to the role playing students can meet with others playing the same role to discuss the nature of their identity. As with the court case role playing, either some persons may be chosen to speak for the group or a more freewheeling format where each person may intervene is possible. If the class is large or the instructor wishes to expand the number participating, small groups may be used to increase the number of role-playing exercises taking place.

This exercise allows (and in some cases requires) students to demonstrate their basic grasp of the material and to move a step beyond by applying the authors' ideas to new material. Once the role playing brings in examples not found in the original selections or points not previously discussed in class, students move quickly to applying and seeing the implications of the authors' ideas. Also, as in the case of court justice role playing, a new and important element of class participation is included: the ability to ask good questions.

As most of us know, asking good questions is not easy. It is a skill that must be nurtured and refined over time (see Andrews 1980, 129-63). Not surprisingly, given the lack of opportunities, it is a skill that many students fail to develop. Furthermore, asking good questions is a form of participation which may not be recognized or adequately rewarded in many classes. Too often participation

\section{For those who may not know, who may be uncertain, or who are simply bashful, the opportunity to participate through asking questions may be an extremely positive and rewarding experience.}

is seen as doing well in debates, espousing ideas, and knowing the correct facts. For those who may not know, who may be uncertain, or who are simply bashful, the opportunity to participate through asking questions may be an extremely positive and rewarding experience.

Some may object that I ask students who originally say they are undecided to choose at the end of the two role-playing exercises. Not knowing is a legitimate position, and forcing persons to choose may be embarrassing and unduly stressful for students. On the other hand, though asking the undecided students to decide at the close of the exercise may seem to put pressure on the more reserved students, it may in fact be liberating. In these exercises I am not looking for the correct answer (i.e., which author is right). Instead, I am asking students for their preference (i.e., with which do you more agree), not which one they wholeheartedly support. If a choice had to be made, what would the choice be and why. Not being able to make a choice at the beginning of the exercise may not mean that a student doesn't have a preference or is unable to decide. It may be that they simply have not thought about the issue or problem, or have not been in a situation where they needed to make a choice. Instead of being oppressive, learning to make and explain choices may be both an important skill and a liberating experience for students. Once they think about a point and make a choice, students frequently admit that they may have had a preference, but were simply not aware of it since they had never seriously thought about the point under consideration.

\section{Brainstorming}

If students are to become independent thinkers, teachers can help by asking students what they think before telling them what we think. Brainstorming is a simple method for encouraging and planting the seeds of autonomous thought. For example, in talks on teaching, instead of telling participants "The Ten Benefits of Class Participation," I ask them to tell me what they think the benefits might be. When a suggestion is given I write the idea on the board along with the name or initials of the person giving the idea. I then return to the list asking each person to say a few words about his or her views on the benefits of participation. In this way it is the participants' ideas that serve as the focus, something they create, and not something I give to them as truth. Similarly, when teaching a class, I often start by asking students for their ideas and observations instead of merely telling them what I think about the question under consideration.

For example, in "Introduction to Public Administration"' I begin by addressing the relationship between bureaucracy (previously discussed in the course) and democracy by asking students to list what they see as the differences and similarities between the two concepts. I write their ideas on the board under two headings, "bureaucracy" and "democracy." Only after examining the students' ideas do I introduce Rosenbloom's 
comparison of bureaucracy and democracy $(1990,404-08)$. The focus of the discussion becomes the differences and similarities between the class's perspective and that presented by Rosenbloom and the validity of each point of view.

In another part of "Introduction to Public Administration"' I introduce evaluation by asking students to think about how one might evaluate their university. After meeting in small groups for 20-25 minutes to develop a plan for evaluating the university, the students report back. I write each group's ideas on the board. With minimal input on my part, the students are generally quick to perceive the strengths and weaknesses of their classmates' proposals and many of the issues involved in designing and implementing an evaluation process (e.g., What is to be measured? Why is this being measured? How is the data to be gathered?). Following the discussion I show the class an actual evaluation of one university and, as when they presented thir own ideas, we proceed to discuss the appropriateness of the questions being asked and the empirical measures being used.

Brainstorming contains an element of guessing. In fact, students are encouraged to guess, to test inchoate ideas, and to follow their feelings about a hunch or possibility. There is no penalty for guessing. The teacher's role is one of helping them to understand and develop those ideas. It is not to see if their thoughts match a preconceived notion of the "right answer." If students feel that their suggestions will not be taken seriously and that the teacher is merely watching them struggle to see if they can arrive at some preconceived idea of the best answer, brainstorming is not geniune and will likely be so perceived by the students. During the course of a class discussion, a student once said to me, "What difference does it make what I think. We are going to talk for a while, and after we are done, you will tell us the answer." While at the time I gave a valiant defense of my approach to teaching, I now see that this student was not only saying what many students perceive but was also speaking a truth about my teaching at that time in my career.
The goal of brainstorming is not to develop the one best list of reasons for class participation or a summary of the only correct ideas on the relation between bureaucracy and democracy. There is not only one list or set of ideas. The goal is to engage participants in the intellectual process and for them to begin to experience its rewards. Through brainstorming students will begin to think on their own and to experience the joys and risks of becoming part of a community of knowing. They learn that in many cases their own ideas do not differ from those of experts in the field and that where differences do occur, expert opinions serve, not as given truth, but as propositions that

\section{Through brainstorming} students will begin to think on their own and to experience the joys and risks of becoming part of a community of knowing.

form the basis for dialogue. Students see that their own ideas, as well as those of the experts, may be accepted, rejected, or modified through discussion and analysis. They learn to become more independent as well as more flexible thinkers.

\section{Demands Placed on Teachers}

Teachers have obligations that must be met if participation is to bring life to the classroom. In addition to being solidly and confidently grounded in one's subject matter, the main job of the teacher is to create an environment that encourages and rewards participation. This is no simple task. It demands that we be flexible, supportive, and patient individuals who are truly sensitive to the variety and individuality of our students. In short, it requires that we possess the skill and courage to be creative and engaged.

Foremost among the skills required is good listening. Being a skilled listener does not come easily, and teachers need to exert the effort needed to be model listeners (Jones 1989). We should not prejudge students before they speak, or let our minds wander (or stop listening) when we see student comments as uninteresting, poorly phrased, or difficult to follow. If we expect students to listen to each other and to us, we ourselves should demonstrate and cultivate good listening skills.

More than skill, however, is needed for genuine class participation. Courage is required, ". . . the courage to expose one's ignorance as well as insight, to invite contradiction as well as consent, to yield some control in order to impower the group, to evoke other people's lives as well as reveal one's own" (Palmer 1990, 16). Like Parker Palmer, I see good teaching as an act of generosity whose success cannot simply be reduced to technique. With some skill and a good deal of courage, class participation provides a means of creating a chemistry that brings teaching alive and gives life to the classroom.

\section{References}

Andrews, John D. W. 1980. "The Verbal Structure of Teacher Questions: Its Impact on Class Discussion." POD Quarterly 2: 129-63.

Brookfield, Stephen D. 1990. The Skillful Teacher: On Technique, Trust, and Responsiveness in the Classroom. San Francisco: Jossey-Bass.

Carnegie Foundation for the Advancement of Teaching. 1990. Campus Life, In Search of Community. Princeton: Carnegie Foundation for the Advancement of Teaching.

Chickering, Arthur W., Zelda F. Gamson, and Louis M. Barsi. 1989. Principles for Good Practice in Undergraduate Education: Faculty Inventory. Racine, WI: The Johnson Foundation.

Day, Ruth S. 1987. "Knowledge Structures: Finding Them and Developing Them." Seventh Annual Lilly Conference on College Teaching, Oxford, OH, November 15.

Eble, Kenneth E. 1976. The Craft of Teaching: $A$ Guide to Mastering the Professor's Art. San Francisco: Jossey-Bass.

1983. The Aims of College Teaching. San Francisco: Jossey-Bass.

Elbow, Peter. 1986. Embracing Contraries. Explorations in Learning and Teaching. New York: Oxford University Press.

Frederick, Peter. 1981. "The Dreaded Discussion: Ten Ways to Start." Improving College and University Teaching 29: 109-14.

Forthcoming. "Discussion: Empowering Students through Practical Stra- 
tegies." In College Teaching: Fresh Approaches to Familiar Problems, Jim Eison and Ohmer Milton, eds. San Francisco: Jossey-Bass.

Jones, Judy. 1989. "Owning the Classroom." First Annual Lilly Conference on College Teaching-West, Lake Arrowhead, California, March 17.

Lowman, Joseph. 1984. Mastering the Techniques of Teaching. San Francisco: Jossey-Bass.

McKeachie, Wilbert J. 1986. Teaching Tips: A Guidebook for the Beginning College Teacher, 8th ed. Lexington, MA: D.C. Heath.

Palmer, Parker J. 1990. "Good Teaching: A
Matter of Living the Mystery." Change January/February: 11-16.

Perry, William G., Jr. 1970. Forms of Intellectual and Ethical Development in the College Years. New York: Holt, Rinehart and Winston.

Rosenbloom, David H. 1990. Public Administration, 2nd ed. New York: Random House.

Study Group on the Conditions of Excellence in American Higher Education. 1984. Involvement in Learning: Realizing the Potential of American Higher Education. Washington, DC: U.S. Department of Education.

\title{
In-Class Debating in Public Law Classes as a Complement to the Socratic Method
}

\author{
Frank Guliuzza III, Weber State University
}

In an introductory American politics course students customarily learn a modicum of public law by memorizing seminal cases and matching them with concepts relating to larger topics, e.g., "rights and liberties" or "the judiciary." Students in advanced courses in public law, however, are usually required to grapple directly with, and to critically evaluate, appellate court cases and constitutional commentaries. Typically, this objective of teaching students how to "teach themselves the law" is accomplished by the technique known as the Socratic method.

The Socratic method, an approach that dominates legal education in the United States, involves asking students, who have presumably already read the assigned cases, to indicate the facts of the case, the legal questions put before the court, how the court answered each question, the reasoning of the majority opinion, and the reasoning behind dissenting or concurring opinions. Then, often in order to answer a series of hypothetical questions by the instructor, students must "harmonize the outcomes of seemingly inconsistent cases so that they are made to stand together." As Howard Abadinsky noted, "By taking and putting together different cases, the student acquires a way of thinking and work- ing with cases that constitutes the fundamentals of legal reasoning, as well as knowledge of doctrinal rules presented by these cases." 1

The Socratic method, however, has not been without its critics. First, it is questionable whether or not instructors want to subject undergraduate students to the same rigors as law students. Political science courses in public law are not mini-law-school classes, and it is not the objective of most instructors in undergraduate classes in constitutional law to get their students to "think like lawyers." Second, there are those who argue that the technique itself actually is damaging to students. ${ }^{2}$

I believe there is a way to teach students to critically evaluate cases, and to expose them to case commentaries as well as the basics of legal research, without relying exclusively on the Socratic method. In my classes in public law, I have each student participate in an in-class debate during the quarter, structured much like competitive debates at the interscholastic or intercollegiate level. Although, for the most part, students are re-arguing cases that have already been decided, they function as the "affirmative" and the "negative" terms in traditional academic debating. The cases serve as the resolution. Both sides present constructive

\section{About the Author}

Mel Cohen is an assistant professor at Miami University Middletown, where he teaches in a number of fields, including American politics, public administration, and comparative politics.

speeches and rebuttal speeches, and they answer cross-examination questions. Further, there is a short writing assignment accompanying the project that obliges the students to argue the merits of their case and to anticipate their opponents' arguments. I have successfully used inclass debating in conjunction with lecturing and the Socratic method.

\section{The Approach}

When summarizing the syllabus and course requirements, 1 indicate to students that they will participate in an in-class debate during the quarter/semester. I explain that each student will argue a case in class. If possible, I will set up the debates so that the student works with a partner to prepare a brief of their case (8-10 pages) and to orally argue the case before the class. If the enrollment makes two-person debating problematic, I will set up the debates to follow a "Lincoln-Douglas" format.

During the first week of class, I pass around a sign-up sheet that lists the cases to be debated and that provides the students with an opportunity to pair up and select a sideappellant/affirmative or appellee/ negative. The cases I select are not landmark decisions that the students 